\title{
Selection for Resistance to the Rhizoctonia-Bacterial Root Rot Complex in Sugar Beet
}

Carl A. Strausbaugh and Imad A. Eujayl, United States Department of Agriculture-Agricultural Research Service NWISRL, Kimberly, ID 83341; and Paul Foote, Amalgamated Sugar Co., Paul, ID 83301 \begin{abstract}
97:93-100.
The Rhizoctonia-bacterial root rot complex continues to be a concerning problem in sugar beet production areas. To investigate resistance to this complex in 26 commercial sugar beet cultivars, field studies and greenhouse studies with mature roots from the field were conducted with Rhizoctonia solani anastomosis group 2-2 IIIB strains and Leuconostoc mesenteroides. Based on means for the 26 cultivars in the 2010 and 2011 field studies, fungal rot ranged from 0 to $8 \%$, bacterial rot ranged from 0 to $37 \%$, total internal rot ranged from 0 to $44 \%$, and surface rot ranged from 0 to $52 \%$. All four rot variables resulted in significant $(P<0.0001)$ cultivar differences. Based on regression
\end{abstract}

Abstract

Strausbaugh, C. A., Eujayl, I. A., and Foote, P. 2013. Selection for resistance to the Rhizoctonia-bacterial root rot complex in sugar beet. Plant Dis. analysis, strong positive relationships $\left(r^{2}\right.$ from 0.6628 to $0.9320 ; P<$ 0.0001 ) were present among the rot variables. When ranking cultivars, the most consistent rot variable was surface rot, because 12 of 13 variable-year combinations had significant $(P \leq 0.05)$ correlations. When cultivar ranking in greenhouse assays was compared, there was frequently a positive correlation with storage data but no relationship with field results. Thus, the greenhouse assays will identify storage rot resistance but field screening will be required to find resistance to this rot complex in the field.
Rhizoctonia root rot caused by Rhizoctonia solani Kühn is of considerable concern in sugar beet production areas in the United States and other areas of the world $(9,15,38)$. Rhizoctonia root rot can lead to root yield losses of $50 \%$ or more but also seems to be on the increase and can be associated with losses in storage $(9,21,27,38,41,43)$. In Idaho, Rhizoctonia root rot on mature roots tends to be associated with the $R$. solani anastomosis group (AG) 2-2 IIIB strains and is frequently accompanied by a bacterial root rot caused by Leuconostoc mesenteroides subsp. dextranicum (Beijerinck) Garvie which leads to a Rhizoctonia-bacterial root rot complex $(36,38,39)$. The prevalence of this rot complex seems to be favored by warmer longer-season production areas, poor crop rotation, and surface irrigations $(38,40)$.

The fungus $R$. solani survives from season to season as propagules in the soil or as mycelia in infested organic matter, while $L$. mesenteroides is widely distributed throughout the environment $(11,13,19,39)$. The genus Leuconostoc is a gram-positive heterofermentative lactic acid bacterium commonly found in soils, sugar factories, fermenting vegetables, dairy products, manure, and wine $(4,11,12,16,19,28,35,47)$. These bacteria are known to be important in the initial phase of fermentation but usually are superseded by other bacteria and yeast $(2,6,16)$. A number of other bacteria and yeast associated with bacterial root rot in sugar beet roots do not cause rot on their own but will slow down rot caused by L. mesen-

Corresponding author: C. A. Strausbaugh,

E-mail: carl.strausbaugh@ars.usda.gov

Mention of trade names or commercial products in this article is solely for the purpose of providing scientific information and does not imply recommendation or endorsement by the United States Department of Agriculture.

* The $\boldsymbol{e}$-Xtra logo stands for "electronic extra" and indicates that a supplementary figure is included in the online edition.

Accepted for publication 1 August 2012.

http://dx.doi.org/10.1094/PDIS-05-12-0511-RE

This article is in the public domain and not copyrightable. It may be freely reprinted with customary crediting of the source. The American Phytopathological Society, 2013. teroides and inhibit $R$. solani $(25,39)$. These bacteria and yeast in competition with $R$. solani may explain why the dry black rot associated with this fungus is typically restricted to the outside of the root and involves only 3 to $5 \%$ of the root mass $(36,40)$. On the other hand, the wet-bacterial rot in this rot complex can be associated with up to $>70 \%$ of the root mass being lost (40).

Our understanding of this rot complex is still developing; therefore, disease control efforts have been targeted at $R$. solani. Crop rotation $(7,8,14,23,31,33)$ and in-furrow or post-emergent banded fungicide sprays $(5,21,22,42,44)$ have been shown to be helpful in controlling Rhizoctonia root rot but relying more on host resistance would be desirable $(17,24,29)$. Thus, to gain a better understanding of the Rhizoctonia-bacterial root rot complex and also how to evaluate sugar beet cultivars for resistance to this complex, a series of field and greenhouse studies were conducted to achieve the following objectives: (i) identify the best disease variable for determining cultivar selection for this rot complex, (ii) determine whether resistance to $R$. solani will also allow for control of bacterial root rot, and (iii) establish an assay under controlled conditions for investigating the rot complex and Rhizoctonia-Leuconostoc interactions.

\section{Materials and Methods}

Rhizoctonia inoculum. The eight $R$. solani AG-2-2 IIIB strains (F304, F508, F512, F517, F521 [this strain's internal transcribed spacer region is genetically identical to that for the R9 strain], F548, F551, and F552) used in the studies had been isolated in Idaho and characterized previously (38). The strains had been stored on sterile barley kernels at $-80^{\circ} \mathrm{C}$. To create inoculum, the strains were first grown on potato dextrose agar (PDA; Becton Dickinson \& Co.) amended with streptomycin sulfate (MP Biomedicals, Inc.) at $200 \mathrm{mg} /$ liter for 10 days. Plugs from these plates were used to inoculate sterile barley (Hordeum vulgare L.) kernels. Before inoculation, the barley kernels had been soaked in tap water for $24 \mathrm{~h}$, then autoclaved for $1 \mathrm{~h}$ at $121^{\circ} \mathrm{C}$. The kernels were then autoclaved a second time for $1 \mathrm{~h}$ the next day. Plugs from the PDA cultures were placed with the barley kernels and incubated in the dark at $21^{\circ} \mathrm{C}$ for approximately 6 weeks. The kernels were then air dried and ground using a Thomas Wiley Laboratory Mill (model 4; GMI Inc.) with a 1-mm screen (modified with 5-mm holes drilled into it). 
Bacterial inoculum. The bacterial suspension of $L$. mesenteroides subsp. dextranicum strain B322 (39) isolated in Idaho was prepare by washing 48 -h yeast-dextrose-calcium carbonate agar (YDC; 34) cultures grown at $30^{\circ} \mathrm{C}$ with sterile tap water. The suspension was adjusted to $10^{8} \mathrm{CFU} / \mathrm{ml}$ with sterile tap water using a BioPhotometer (Eppendorf AG) and confirmed with a 10-fold dilution series on YDC.

Isolations. Isolations for $R$. solani were conducted on PDA amended with streptomycin sulfate at $200 \mathrm{mg} / \mathrm{liter}$. Isolations for $L$. mesenteroides were conducted on glucose, yeast extract, peptone agar (glucose, $10.0 \mathrm{~g}$; yeast extract, $5.0 \mathrm{~g}$; peptone, $5.0 \mathrm{~g}$; sodium acetate $2.0 \mathrm{~g}$; Tween $80,0.25 \mathrm{~g} ; \mathrm{MgSO}_{4} \cdot 7 \mathrm{H}_{2} \mathrm{O}, 0.2 \mathrm{~g} ; \mathrm{MnSO}_{4}$. $4 \mathrm{H}_{2} \mathrm{O}, 0.01 \mathrm{~g} ; \mathrm{FeSO}_{4} \cdot 7 \mathrm{H}_{2} \mathrm{O}, 0.01 \mathrm{~g} ; \mathrm{NaCl}, 5.0 \mathrm{~g} ; \mathrm{CaCO}_{3}, 5.0 \mathrm{~g}$; agar, $20 \mathrm{~g}$; and $1,000 \mathrm{ml}$ of reverse osmosis water; adjusted to $\mathrm{pH}$ 6.8) with bromocresol purple $(0.04 \mathrm{~g} /$ liter $)$ amended with tetracycline $(0.2 \mathrm{mg} / \mathrm{liter})$ and vancomycin $(0.03 \mathrm{~g} / \mathrm{liter})$ to make it semiselective for Leuconostoc spp. $(4,10)$.

Field cultivar trial. Because sugar beet cultivars had not been previously investigated for the Rhizoctonia-bacterial root rot complex, roots from 26 commercial cultivars (Table 1), 2 check lines (FC901/C817 $=R$. solani -susceptible check and FC705/1 $=R$. solani-resistant check; both checks provided by the United States Department of Agriculture-Agricultural Research Service sugarbeet program in Ft. Collins, $\mathrm{CO}$ ), and a noninoculated commercial check 'B-5' (contact Betaseed Inc. with code for more information on this cultivar) were evaluated for Rhizoctonia-bacterial root rot in a field trial conducted in Kimberly, ID in 2010. Plots were planted on 3 May in a randomized complete block design with six replications. The seed was treated with the insecticide clothianidin (Bayer CropScience) at $60 \mathrm{~g}$ a.i. per 100,000 seed and the fungicides metalaxyl (Bayer CropScience) at $15.6 \mathrm{~g}$ a.i. per $100 \mathrm{~kg}$ of seed and thiram (Bayer CropScience) at $250 \mathrm{~g}$ a.i. per $100 \mathrm{~kg}$ of seed to allow for good stand establishment and protection against early-season pest problems. The plots were planted to a density of 352,123 seeds/ha and thinned at the four-leaf growth stage to 117,374 plants/ha. Plots were single rows with $56-\mathrm{cm}$ row spacing, $3 \mathrm{~m}$ in length, and irrigated with solid set handlines. Trials were managed using standard crop production practices. However, weed management did not include glyphosate, because the FC check lines were not glyphosate resistant. Weed control was accomplished with a preplant ethotron (42\% ethofumesate) application of 2.33 liters/ha and hand weeding. Plants were inoculated on 28 June in the crown at the eight-leaf growth stage with dried ground barley inoculum of the $R$. solani AG-2-2 IIIB strain F517 at 0.6 $\mathrm{g} /$ plant. No soil was knocked into the crown area, because cultivation is no longer a common practice with growers having switched to glyphosate-resistant cultivars. No root or foliar diseases or pests were evident at the time of harvest other than the Rhizoctoniabacterial root rot complex. The first 10 roots in each row were evaluated visually for surface rot (percentage of root surface with dry black rot) on 10 September from each plot. These roots were also bisected to determine visually the percentage of root mass associated with fungal rot (dry black rot) and bacterial rot (wet rot). Isolations from 15 roots were conducted to confirm the pres-

Table 1. Rhizoctonia and bacterial root rot measured on 10 September 2010 in 26 commercial sugar beet cultivars and 2 check cultivars or lines inoculated with Rhizoctonia solani anastomosis group 2-2 IIIB strain F517 in a field trial conducted in Kimberly, ID

\begin{tabular}{|c|c|c|c|c|}
\hline \multirow[b]{2}{*}{ Cultivar $^{\mathrm{y}}$} & \multicolumn{3}{|c|}{ Internal root mass rotted $(\%)^{x}$} & \multirow[b]{2}{*}{ Surface $^{x}(\%)$} \\
\hline & Fungal & Bacterial & Total & \\
\hline B-5 & $8.0 \mathrm{a}$ & $29.3 \mathrm{a}$ & $37 \mathrm{a}$ & $52 \mathrm{a}$ \\
\hline $\mathrm{C}-25$ & $8.1 \mathrm{a}$ & $16.6 \mathrm{bc}$ & $25 \mathrm{~b}$ & $49 \mathrm{ab}$ \\
\hline HM080006 & $5.7 \mathrm{a}-\mathrm{c}$ & $10.4 \mathrm{~b}-\mathrm{g}$ & $16 \mathrm{~b}-\mathrm{d}$ & $44 a-c$ \\
\hline HM080004 & $6.4 \mathrm{ab}$ & $19.4 \mathrm{~b}$ & $26 \mathrm{ab}$ & $42 \mathrm{a}-\mathrm{d}$ \\
\hline B-7 & $6.1 \mathrm{ab}$ & $8.4 \mathrm{c}-\mathrm{h}$ & $14 \mathrm{~b}-\mathrm{f}$ & $36 \mathrm{~b}-\mathrm{e}$ \\
\hline $\mathrm{C}-28$ & $5.9 \mathrm{a}-\mathrm{c}$ & $10.7 \mathrm{~b}-\mathrm{f}$ & $17 \mathrm{bc}$ & $36 b-e$ \\
\hline $\mathrm{C}-29$ & $5.1 \mathrm{~b}-\mathrm{d}$ & $11.9 \mathrm{~b}-\mathrm{d}$ & $17 \mathrm{bc}$ & $35 \mathrm{~b}-\mathrm{e}$ \\
\hline HM080011 & $4.9 \mathrm{~b}-\mathrm{e}$ & $7.2 \mathrm{c}-\mathrm{h}$ & $12 \mathrm{c}-\mathrm{g}$ & $34 \mathrm{c}-\mathrm{f}$ \\
\hline B-37 & $4.8 \mathrm{~b}-\mathrm{f}$ & $11.3 \mathrm{~b}-\mathrm{e}$ & $16 \mathrm{~b}-\mathrm{e}$ & $32 c-g$ \\
\hline HH016 & $4.8 \mathrm{~b}-\mathrm{f}$ & $6.9 \mathrm{~d}-\mathrm{h}$ & $12 \mathrm{c}-\mathrm{h}$ & $31 \mathrm{c}-\mathrm{h}$ \\
\hline B-39 & $3.9 \mathrm{~b}-\mathrm{g}$ & $7.4 \mathrm{c}-\mathrm{h}$ & $11 \mathrm{c}-\mathrm{h}$ & $28 \mathrm{~d}-\mathrm{i}$ \\
\hline FC901/C817 & $4.8 \mathrm{~b}-\mathrm{f}$ & $6.2 \mathrm{~d}-\mathrm{h}$ & $11 \mathrm{c}-\mathrm{h}$ & $27 \mathrm{e}-\mathrm{j}$ \\
\hline C-19 & $4.0 \mathrm{~b}-\mathrm{g}$ & $5.4 \mathrm{~d}-\mathrm{h}$ & $9 \mathrm{c}-\mathrm{h}$ & $27 \mathrm{e}-\mathrm{k}$ \\
\hline SV007 & $3.3 \mathrm{c}-\mathrm{h}$ & $7.9 \mathrm{c}-\mathrm{h}$ & $11 \mathrm{c}-\mathrm{h}$ & $26 \mathrm{e}-\mathrm{k}$ \\
\hline $\mathrm{C}-27$ & $2.9 \mathrm{~d}-\mathrm{h}$ & $3.5 \mathrm{~d}-\mathrm{h}$ & $6 \mathrm{c}-\mathrm{h}$ & $22 \mathrm{e}-\mathrm{k}$ \\
\hline B-38 & $2.5 \mathrm{e}-\mathrm{i}$ & $2.1 \mathrm{e}-\mathrm{h}$ & $5 \mathrm{e}-\mathrm{h}$ & $20 \mathrm{f}-\mathrm{k}$ \\
\hline HM070022 & $2.0 \mathrm{~g}-\mathrm{i}$ & $2.7 \mathrm{~d}-\mathrm{h}$ & $5 \mathrm{~d}-\mathrm{h}$ & $19 \mathrm{f}-\mathrm{k}$ \\
\hline SV001 & $2.2 \mathrm{~g}-\mathrm{i}$ & $4.9 \mathrm{~d}-\mathrm{h}$ & $7 \mathrm{c}-\mathrm{h}$ & $17 \mathrm{~g}-\mathrm{k}$ \\
\hline $\mathrm{C}-11$ & $2.2 \mathrm{f}-\mathrm{i}$ & $2.7 \mathrm{~d}-\mathrm{h}$ & $5 \mathrm{~d}-\mathrm{h}$ & $16 \mathrm{~h}-\mathrm{k}$ \\
\hline C-208 & $1.8 \mathrm{~g}-\mathrm{i}$ & $1.8 \mathrm{f}-\mathrm{h}$ & $4 \mathrm{f}-\mathrm{h}$ & $16 \mathrm{i}-1$ \\
\hline НH017 & $1.7 \mathrm{~g}-\mathrm{i}$ & $1.1 \mathrm{gh}$ & $3 \mathrm{gh}$ & $14 \mathrm{i}-1$ \\
\hline SV003 & $1.4 \mathrm{~g}-\mathrm{i}$ & $1.3 \mathrm{f}-\mathrm{h}$ & $3 \mathrm{gh}$ & $14 \mathrm{i}-1$ \\
\hline C-204 & $1.6 \mathrm{~g}-\mathrm{i}$ & $0.9 \mathrm{~h}$ & $3 \mathrm{gh}$ & $13 \mathrm{i}-1$ \\
\hline HH015 & $1.4 \mathrm{~g}-\mathrm{i}$ & $0.5 \mathrm{~h}$ & $2 \mathrm{gh}$ & $13 \mathrm{i}-1$ \\
\hline $\mathrm{C}-12$ & $1.6 \mathrm{~g}-\mathrm{i}$ & $4.2 \mathrm{~d}-\mathrm{h}$ & $6 \mathrm{c}-\mathrm{h}$ & $13 \mathrm{i}-1$ \\
\hline B-34 & $2.0 \mathrm{~g}-\mathrm{i}$ & $1.9 \mathrm{e}-\mathrm{h}$ & $4 \mathrm{f}-\mathrm{h}$ & $12 \mathrm{j}-1$ \\
\hline HM070006 & $1.2 \mathrm{hi}$ & $0.8 \mathrm{~h}$ & $2 \mathrm{gh}$ & $12 \mathrm{kl}$ \\
\hline FC705/1 & $0.1 \mathrm{i}$ & $0.0 \mathrm{~h}$ & $0 \mathrm{~h}$ & 11 \\
\hline Noninoculated check & $0.0 \mathrm{i}$ & $0.0 \mathrm{~h}$ & $0 \mathrm{~h}$ & 01 \\
\hline Overall mean & 3.5 & 12.4 & 10 & 24 \\
\hline$P>F^{\mathrm{Z}}$ & $<0.0001$ & $<0.0001$ & $<0.0001$ & $<0.0001$ \\
\hline
\end{tabular}

${ }^{\mathrm{x}}$ Fungal = percentage of rotted root mass associated with dry black rot caused by $R$. solani, Bacterial = percentage of rotted root mass associated with wet rot (relied on natural inoculum for Leuconostoc mesenteroides), Total = percentage of internal root mass associated with fungal and bacterial rot, and Surface $=$ percentage of root surface with a dry black rot caused by $R$. solani . Means within a column followed by the same letter did not differ significantly based on least square means $(\alpha=0.05)$.

y All cultivar names are coded (B = Betaseed Inc., C = ACH Seed Inc., HH = Holly Hybrids, HM = Hilleshog, and SV = SESVanderHave) but the respective companies can be contacted using the code to gain additional information on the cultivars. FC $901 / \mathrm{C} 817$ (susceptible) and FC705/1 (resistant) were the $R$. solani check cultivars provided by the United States Department of Agriculture-Agricultural Research Service sugar beet program in Ft. Collins, CO. B-5 was the noninoculated check cultivar.

${ }^{\text {z }} P>F$ was the probability associated with the $F$ value. Data were analyzed in SAS using Proc GLIMMIX. 
ence of $R$. solani and L. mesenteroides as described in the Isolation subsection.

The experiment was repeated in 2011 with the same methods and cultivars as in 2010. Seed were planted on 4 May and inoculated on the 23 June (eight-leaf growth stage). No root or foliar diseases or pests were evident at the time of harvest other than the Rhizoctonia-bacterial root rot complex. Disease evaluations were conducted on 12 September.

$\boldsymbol{R}$. solani strain comparison. In an effort to find a method for comparing $R$. solani and $L$. mesenteroides strains under controlled conditions, a greenhouse assay using mature sugar beet roots from the field was investigated. This root rot assay was conducted to compare eight $R$. solani AG-2-2 IIIB strains (F304, F508, F512, F517, F521, F548, F551, and F552) and the L. mesenteroides subsp. dextranicum strain B322 inoculated individually and in combination on roots of the commercial sugar beet B-5. The healthy-appearing mature roots used in the assay were grown in Kimberly, ID using standard production practices. The roots were hand dug and topped and inoculated on 3 September 2009. Each root was inoculated in three places ( $R$. solani only, L. mesenteroides only, and $R$. solani $+L$. mesenteroides) in the shoulder (widest portion of root) of the root. A noninoculated check was also included. From each root, three plugs $(8 \mathrm{~mm}$ in diameter and $24 \mathrm{~mm}$ in length) equally spaced around the root were removed from the shoulder of the root with a cork borer (Supplementary Figure S1). One hole was inoculated with $0.06 \mathrm{~g}$ of ground barley infested with an $R$. solani strain. A second hole was inoculated with $0.06 \mathrm{~g}$ of $R$. solani and a $0.2-\mathrm{ml}$ suspension $\left(10^{8} \mathrm{CFU} / \mathrm{ml}\right)$ containing $L$. mesenteroides. A third hole was inoculated with just the 0.2-ml suspension of $L$. mesenteroides. The noninoculated check had plugs pulled and replaced but no inoculum was inserted. Once the plugs were replaced, they were then sealed with petroleum jelly (100\% white petrolatum USP, distributed by Albertsons, Inc.). Each root served as an experimental unit and was arranged in a randomized complete block design with six replications. The roots were placed on the cement floor of a greenhouse (low and high temperature set points were 18 and $27^{\circ} \mathrm{C}$, respectively) under a greenhouse bench and covered with a nylon tarp (which minimized desiccation but still allowed for some air exchange). A second nylon tarp was draped over the greenhouse bench to keep the tarp directly covering the roots out of direct sunlight. After 2 weeks, the roots were cross sectioned (sliced along the length of the plug; and the rotted area was measured perpendicular to the plug. At the time of rot evaluation, isolations from seven roots at all three inoculation points were conducted to confirm the presence of the inoculated organism or contaminants. The experiment was repeated the next year on 15 September 2010 using the same methods.

Greenhouse assay at harvest. The same 26 commercial sugar beet cultivars compared in the field assay were also compared in a greenhouse assay using methods similar to those described above in the $R$. solani strain assay subsection. The roots used in the assay were grown in American Falls, ID as part of a cultivar trial. The trial was managed using standard cultural practices and had been planted on 13 April 2009. The roots were harvested using a mechanical harvester on 28 September 2009 and inoculated the next day. The greenhouse assay maintained the roots in the same randomized complete block design with six replications that was used in the field. The experimental unit for the greenhouse assay was a single healthy-appearing mature root from each cultivar. From each root, three plugs were pulled and inoculated as described in the $R$. solani strain assay, while the $R$. solani AG-2-2 IIIB strain F508 and bacterial strain L. mesenteroides subsp. dextranicum strain B322 served as inoculum sources. After 3 weeks, the roots were cross sectioned (sliced along the length of the plug) and the diameter of the rotted area was measured perpendicular to plug. At the time of rot evaluation, isolations from 28 roots (all three inoculation points) were conducted to confirm the presence of the inoculated organism or contaminants. The assay was repeated the next year in 2010 with the same methods and cultivars while using roots from a field planted on 16 April in American Falls, ID and harvested on 27 September and inoculated the next day.

Greenhouse assay after storage. In an effort to determine whether the greenhouse assay using roots at harvest was related more to conditions in the field or during storage, the greenhouse root rot assay in 2009 was conducted with a second set of roots from the same plots as the assay conducted at harvest. Storing the roots in a cold room at $4{ }^{\circ} \mathrm{C}$ and $90 \%$ relative humidity for 60 days was the only change from the greenhouse assay at harvest time. The rest of the methods were the same as the greenhouse root assay at harvest, except the incubation period was reduced to 2 weeks, because the roots were in a weakened state from storage and some fungal contaminants were established on the root surface. The assay was repeated in 2010 using the same cultivars and methods as the previous year.

Data analysis. The SAS (version 9.2; SAS Institute Inc.) Univariate procedure was used to test for normality of the data. Disease variables were investigated using the SAS general linear mixed models procedure (Proc GLIMMIX). In the model statement, the fixed effect was treatment, the random effect was block, and the denominator degrees of freedom were calculated using the DDFM=KENWARDRODGER option. Mean comparisons were conducted using least squared means (LSMEANS) statement $(\alpha=$ 0.05) while using the "lines" option to generate the output. Correlations based on regression analysis (Proc REG) and Spearman's coefficient of rank correlation and were also conducted with SAS. When means are followed by $\pm x, x$ refers to the standard error.

\section{Results}

Field cultivar trial. Based on means from the 2010 and 2011 field studies, fungal rot ranged from 0 to $8 \%$, bacterial rot ranged from 0 to $37 \%$, total internal root rot ranged from 0 to $44 \%$, and surface rot ranged from 0 to $52 \%$ (Tables 1 and 2). Based on regression analysis with the 2010 data, the positive relationships between surface rot and fungal $\left(r^{2}=0.8629, P<0.0001\right)$, bacterial $\left(r^{2}=0.7008, P<0.0001\right)$, and total internal root $\left(r^{2}=0.7890, P<\right.$ $0.0001)$ rots were all significant. Based on regression analysis with the 2011 data, the positive relationships between surface rot and fungal $\left(r^{2}=0.8798, P<0.0001\right)$, bacterial $\left(r^{2}=0.9164, P<\right.$ $0.0001)$, and total internal root $\left(r^{2}=0.9320, P<0.0001\right)$ rots were also significant. Based on regression analysis, there was also a positive relationship between fungal and bacterial rot in $2010\left(r^{2}=\right.$ $0.6628, P<0.0001)$ and $2011\left(r^{2}=0.8073, P<0.0001\right)$. All four disease variables resulted in significant $(P<0.0001)$ cultivar differences for both years (Tables 1 and 2). Based on surface rot, 'B-7', 'HM080006', and 'C-25' ranked lower than the susceptible check in both years. 'C-204', 'C-208', 'HH017', and 'HM070006' were among the most resistant cultivars and not significantly different from the resistant and noninoculated checks both years. The Spearman's rank coefficients for 21 of the 28 variable-year comparisons were significant (Table 3 ). The most consistent variable to use for cultivar ranking was surface rot, because 12 of 13 variable-year combinations were significant (Table 3). The other variables, in decreasing order of consistency, were fungal rot (11 of 13 were significant), total internal rot ( 9 of 13), and bacterial rot (8 of 13). Based on isolations from 30 roots (15 each year), $R$. solani could be confirmed in $73 \%$ of the roots while L. mesenteroides could be confirmed in $35 \%$ of the roots. Isolations were frequently hindered by bacterial and yeast contaminants.

$\boldsymbol{R}$. solani strain comparison. With the Rhizoctonia inoculation, all $R$. solani strains were pathogenic based on a comparison with the noninoculated check (Table 4 ). There were significant differences between strains at times but significant separation of strains was not consistent between years. With the Rhizoctonia + Leuconostoc inoculation, all strain combinations resulted in significant rot based on a comparison with the noninoculated check (Table 4). On average, the amount of rot doubled both years when L. mesenteroides was inoculated with $R$. solani. In 2009 and 2010 without 
the noninoculated check, the Rhizoctonia inoculation had a mean rot of $12 \pm 3$ and $16 \pm 2 \mathrm{~mm}$, respectively, while the Rhizoctonia + Leuconostoc inoculation had a mean rot of $26 \pm 2$ and $32 \pm 9 \mathrm{~mm}$, respectively. When $L$. mesenteroides was inoculated alone, no rot occurred. Based on isolations from 14 roots ( 7 per year), $R$. solani could be confirmed $100 \%$ of the time in the Rhizoctonia inoculation, whereas it was isolated only $21 \%$ of the time when inoculated with Leuconostoc. On the other hand, L. mesenteroides could be confirmed $79 \%$ of the time in the Rhizoctonia + Leuconostoc inoculation but was also isolated $50 \%$ of the time in the Rhizoctonia inoculation.

Greenhouse assay at harvest and after storage. The $R h i$ zoctonia and Rhizoctonia + Leuconostoc inoculations resulted in rot in all roots for the greenhouse assays at harvest and differences between cultivars in both years (Table 5). After 60 days in storage, the same inoculations resulted in rot in all roots but differences between cultivars could only be established for the Rhizoctonia + Leuconostoc inoculation in 2009 (Table 6). Cultivar rankings for the

Table 2. Rhizoctonia and bacterial root rot measured during 12 September 2011 in 26 commercial sugar beet cultivars and 2 check cultivars or lines inoculated with Rhizoctonia solani anastomosis group 2-2 IIIB strain F517 in a field trial conducted in Kimberly, ID

\begin{tabular}{|c|c|c|c|c|}
\hline \multirow[b]{2}{*}{ Cultivar $^{y}$} & \multicolumn{3}{|c|}{ Internal root mass rotted $(\%)^{x}$} & \multirow[b]{2}{*}{ Surface $(\%)$} \\
\hline & Fungal & Bacterial & Total & \\
\hline $\mathrm{B}-7$ & $6.4 \mathrm{a}$ & $37.1 \mathrm{a}$ & $44 \mathrm{a}$ & $52 \mathrm{a}$ \\
\hline HM080006 & $5.4 \mathrm{a}-\mathrm{c}$ & $28.5 \mathrm{a}-\mathrm{d}$ & $34 a-d$ & $49 \mathrm{ab}$ \\
\hline HH015 & $5.6 \mathrm{ab}$ & $36.6 \mathrm{a}$ & $42 \mathrm{ab}$ & $46 a-c$ \\
\hline $\mathrm{C}-19$ & $5.0 \mathrm{a}-\mathrm{c}$ & $33.8 \mathrm{a}-\mathrm{c}$ & $39 a-c$ & $44 a-d$ \\
\hline C- 25 & $5.0 \mathrm{a}-\mathrm{d}$ & $28.0 \mathrm{a}-\mathrm{d}$ & $33 \mathrm{a}-\mathrm{d}$ & $42 \mathrm{a}-\mathrm{e}$ \\
\hline SV001 & $5.3 \mathrm{a}-\mathrm{c}$ & $28.0 \mathrm{a}-\mathrm{d}$ & $33 a-d$ & $41 \mathrm{a}-\mathrm{f}$ \\
\hline HM070022 & $4.1 \mathrm{~b}-\mathrm{g}$ & $34.6 \mathrm{a}-\mathrm{c}$ & $39 a-c$ & $40 \mathrm{a}-\mathrm{f}$ \\
\hline FC901/C817 & $4.2 \mathrm{a}-\mathrm{f}$ & $28.0 \mathrm{a}-\mathrm{d}$ & $32 \mathrm{a}-\mathrm{d}$ & $38 \mathrm{a}-\mathrm{g}$ \\
\hline $\mathrm{C}-29$ & $4.6 \mathrm{a}-\mathrm{e}$ & $25.4 \mathrm{a}-\mathrm{e}$ & $30 \mathrm{a}-\mathrm{e}$ & $37 \mathrm{a}-\mathrm{g}$ \\
\hline B-37 & $4.9 \mathrm{a}-\mathrm{e}$ & $26.6 \mathrm{a}-\mathrm{e}$ & $32 \mathrm{a}-\mathrm{e}$ & $36 \mathrm{a}-\mathrm{g}$ \\
\hline B-38 & $4.3 \mathrm{a}-\mathrm{f}$ & $24.5 \mathrm{a}-\mathrm{f}$ & $29 \mathrm{a}-\mathrm{e}$ & $34 \mathrm{a}-\mathrm{h}$ \\
\hline $\mathrm{C}-12$ & $4.6 \mathrm{a}-\mathrm{e}$ & $15.6 \mathrm{~d}-\mathrm{h}$ & $20 \mathrm{c}-\mathrm{h}$ & $29 \mathrm{~b}-\mathrm{i}$ \\
\hline B-5 & $3.6 \mathrm{~b}-\mathrm{h}$ & $11.2 \mathrm{~d}-\mathrm{h}$ & $15 \mathrm{~d}-\mathrm{h}$ & $27 \mathrm{c}-\mathrm{i}$ \\
\hline HM080004 & $3.6 \mathrm{~b}-\mathrm{h}$ & $14.5 \mathrm{~d}-\mathrm{h}$ & $18 \mathrm{~d}-\mathrm{h}$ & $26 c-i$ \\
\hline SV003 & $3.3 \mathrm{c}-\mathrm{h}$ & $18.8 \mathrm{~b}-\mathrm{g}$ & $22 \mathrm{~b}-\mathrm{f}$ & $25 \mathrm{~d}-\mathrm{i}$ \\
\hline SV007 & $3.4 \mathrm{~b}-\mathrm{h}$ & $17.5 \mathrm{c}-\mathrm{h}$ & $21 \mathrm{c}-\mathrm{g}$ & $24 \mathrm{~d}-\mathrm{i}$ \\
\hline $\mathrm{C}-28$ & $3.4 \mathrm{~b}-\mathrm{h}$ & $15.3 \mathrm{~d}-\mathrm{h}$ & $19 \mathrm{c}-\mathrm{h}$ & $21 \mathrm{e}-\mathrm{j}$ \\
\hline B-39 & $2.8 \mathrm{~d}-\mathrm{i}$ & $12.8 \mathrm{~d}-\mathrm{h}$ & $16 \mathrm{~d}-\mathrm{h}$ & $20 \mathrm{f}-\mathrm{j}$ \\
\hline $\mathrm{C}-27$ & $2.2 \mathrm{f}-\mathrm{j}$ & $11.6 \mathrm{~d}-\mathrm{h}$ & $14 \mathrm{~d}-\mathrm{h}$ & $18 \mathrm{~g}-\mathrm{j}$ \\
\hline B-34 & $2.7 \mathrm{e}-\mathrm{i}$ & $8.7 \mathrm{e}-\mathrm{h}$ & $11 \mathrm{e}-\mathrm{h}$ & $17 \mathrm{~g}-\mathrm{j}$ \\
\hline HH016 & $3.6 \mathrm{~b}-\mathrm{h}$ & $11.2 \mathrm{~d}-\mathrm{h}$ & $15 \mathrm{~d}-\mathrm{h}$ & $17 \mathrm{~g}-\mathrm{j}$ \\
\hline HM080011 & $1.8 \mathrm{~h}-\mathrm{k}$ & $4.8 \mathrm{gh}$ & $7 \mathrm{f}-\mathrm{h}$ & $14 \mathrm{~h}-\mathrm{j}$ \\
\hline C-208 & $1.8 \mathrm{~g}-\mathrm{k}$ & $3.6 \mathrm{gh}$ & $5 \mathrm{f}-\mathrm{h}$ & $13 \mathrm{~h}-\mathrm{j}$ \\
\hline C-204 & $1.7 \mathrm{~h}-\mathrm{k}$ & $6.1 \mathrm{gh}$ & $8 \mathrm{f}-\mathrm{h}$ & $13 \mathrm{ij}$ \\
\hline HH017 & $1.8 \mathrm{~h}-\mathrm{k}$ & $6.5 \mathrm{f}-\mathrm{h}$ & $8 \mathrm{f}-\mathrm{h}$ & $11 \mathrm{ij}$ \\
\hline $\mathrm{C}-11$ & $1.0 \mathrm{i}-\mathrm{k}$ & $0.4 \mathrm{~h}$ & $1 \mathrm{gh}$ & $3 \mathrm{j}$ \\
\hline HM070006 & $0.2 \mathrm{jk}$ & $0.0 \mathrm{~h}$ & $0 \mathrm{~h}$ & $1 \mathrm{j}$ \\
\hline FC705/1 & $0.0 \mathrm{k}$ & $0.0 \mathrm{~h}$ & $0 \mathrm{~h}$ & $1 \mathrm{j}$ \\
\hline Noninoculated check & $0.0 \mathrm{k}$ & $0.0 \mathrm{~h}$ & $0 \mathrm{~h}$ & $0 \mathrm{j}$ \\
\hline Overall mean & 3.3 & 16.9 & 20 & 26 \\
\hline$P>F^{\mathrm{z}}$ & $<0.0001$ & $<0.0001$ & $<0.0001$ & $<0.0001$ \\
\hline
\end{tabular}

${ }^{\mathrm{x}}$ Fungal = percentage of rotted root mass associated with dry black rot caused by $R$. solani, Bacterial = percentage of rotted root mass associated with wet rot (relied on natural inoculum for Leuconostoc mesenteroides), Total $=$ percentage of root mass associated with fungal and bacterial rot, and Surface $=$ percentage of root surface with a dry black rot caused by $R$. solani. Means within a column followed by the same letter did not differ significantly based on least square means $(\alpha=0.05)$

${ }^{y}$ All cultivar names are coded (B = Betaseed Inc., C = ACH Seed Inc., HH = Holly Hybrids, HM = Hilleshog, and SV = SESVanderHave) but the respective companies can be contacted using the code to gain additional information on the cultivars. FC901/C817 (susceptible) and FC705/1 (resistant) were the $R$. solani check cultivars provided by the United States Department of Agriculture-Agricultural Research Service sugar beet program in Ft. Collins, CO. B-5 was the noninoculated check cultivar.

${ }^{\mathrm{z}} P>F$ was the probability associated with the $F$ value. Data were analyzed in SAS using Proc GLIMMIX.

Table 3. Spearman's rank correlation on 26 commercial sugar beet cultivars evaluated for the Rhizoctonia-bacterial root rot complex after being inoculated in the field during the 2010 and 2011 growing seasons with the Rhizoctonia solani anastomosis group 2-2 IIIB strain F517 in Kimberly, ID

\begin{tabular}{|c|c|c|c|c|c|c|c|c|}
\hline \multirow[b]{3}{*}{ Variable $^{\mathrm{z}}$} & \multicolumn{6}{|c|}{ Internal } & & \\
\hline & \multicolumn{2}{|c|}{ Fungal rot } & \multicolumn{2}{|c|}{ Bacterial rot } & \multicolumn{2}{|c|}{ Total rot } & \multicolumn{2}{|c|}{ Surface rot } \\
\hline & 2010 & 2011 & 2010 & 2011 & 2010 & 2011 & 2010 & 2011 \\
\hline Fungal rot 2010 & 1.000 & & $\ldots$ & $\ldots$ & $\ldots$ & $\ldots$ & $\ldots$ & $\ldots$ \\
\hline Fungal rot 2011 & $0.393 * *$ & 1.000 & $\ldots$ & $\ldots$ & $\ldots$ & $\ldots$ & $\ldots$ & $\ldots$ \\
\hline Bacterial rot 2010 & $0.933 * *$ & $0.420 * *$ & 1.000 & $\ldots$ & $\ldots$ & $\ldots$ & $\ldots$ & $\ldots$ \\
\hline Bacterial rot 2011 & 0.263 & $0.918 * *$ & 0.283 & 1.000 & $\ldots$ & $\ldots$ & $\ldots$ & $\ldots$ \\
\hline Total rot 2010 & $0.956 * *$ & $0.423 * *$ & $0.991 * *$ & 0.269 & 1.000 & $\cdots$ & $\cdots$ & $\cdots$ \\
\hline Total rot 2011 & 0.274 & $0.930 * *$ & 0.297 & $0.997 * *$ & 0.285 & 1.000 & & $\ldots$ \\
\hline Surface rot 2010 & $0.972 * *$ & $0.422 * *$ & $0.927 * *$ & 0.317 & $0.948 * *$ & $0.327 *$ & 1.000 & $\ldots$ \\
\hline Surface rot 2011 & $0.388^{* *} *$ & $0.966 * *$ & $0.410 * *$ & $0.956 * *$ & $0.403 * *$ & $0.963 * *$ & $0.434 * *$ & 1.000 \\
\hline
\end{tabular}

${ }^{\mathrm{z}}$ Fungal rot $=$ percentage of internal root mass associated with Rhizoctonia root rot, Bacterial rot $=$ percentage of internal root mass associated with bacterial root rot, Total rot = fungal and bacterial rot combined, Surface rot $=$ percentage of root surface area discolored by root rot, $* *=r$ value significant with $P \leq 0.05$, and $*=r$ value significant with $P \leq 0.10$. Although $R$. solani had been inoculated, the bacterial rot relied on natural infestation by Leuconostoc mesenteroides. 
Table 4. Diameter of rotted area after 2 weeks in a greenhouse root assay from six Rhizoctonia solani anastomosis group (AG)-2-2 IIIB strains inoculated alone and in combination with Leuconostoc mesenteroides subsp. dextranicum strain B322 into mature sugar beet roots of commercial sugar beet 'B-5' hand harvested from disease-free field plots in 2009 and 2010 from Kimberly, ID

\begin{tabular}{|c|c|c|c|c|}
\hline \multirow[b]{3}{*}{ Strain $^{y}$} & \multicolumn{4}{|c|}{$\operatorname{Root} \operatorname{rot}(\mathrm{mm})^{x}$} \\
\hline & \multicolumn{2}{|c|}{ Rhizoctonia } & \multicolumn{2}{|c|}{ Rhizoctonia + Leuconostoc } \\
\hline & 2009 & 2010 & 2009 & 2010 \\
\hline F521 & $10 \mathrm{~b}$ & $18 \mathrm{ab}$ & $24 \mathrm{ab}$ & $41 \mathrm{a}$ \\
\hline F551 & ND & $16 a b$ & ND & $40 \mathrm{a}$ \\
\hline F552 & ND & $16 \mathrm{ab}$ & ND & $38 \mathrm{a}$ \\
\hline F548 & $13 \mathrm{ab}$ & $19 \mathrm{a}$ & $28 \mathrm{a}$ & $27 \mathrm{a}$ \\
\hline F508 & $10 \mathrm{~b}$ & $13 \mathrm{~b}$ & $29 \mathrm{a}$ & $24 \mathrm{a}$ \\
\hline F517 & $16 \mathrm{a}$ & $14 \mathrm{ab}$ & $22 \mathrm{~b}$ & $21 \mathrm{a}$ \\
\hline Check & $0 \mathrm{c}$ & $0 \mathrm{c}$ & $0 \mathrm{c}$ & $0 \mathrm{~b}$ \\
\hline Mean & 10 & 14 & 21 & 27 \\
\hline$P>F^{\mathrm{z}}$ & $<0.0001$ & $<0.0001$ & $<0.0001$ & 0.0054 \\
\hline
\end{tabular}

${ }^{\mathrm{x}}$ Rhizoctonia $=$ root inoculated with $R$. solani strain. Rhizoctonia + Leuconostoc $=$ root inoculated with $R$. solani strain plus $L$. mesenteroides subsp. dextranicum strain B322. Means within a column followed by the same letter did not differ significantly based on least square means ( $\alpha=$ $0.05) ; \mathrm{ND}=$ no data.

${ }^{\text {y }} R$. solani AG-2-2 IIIB strains from Idaho; Check = noninoculated check and Mean $=$ overall mean.

${ }^{\mathrm{z}} P>F$ was the probability associated with the $F$ value. Data were analyzed in SAS using the Proc GLIMMIX procedure.
2009 and 2010 Rhizoctonia inoculations at harvest were positively related in 6 of the 8 year-treatment combinations associated with storage data, whereas there were no relationships with all 16 yeartreatment combinations associated with field data (Table 7). When considering the Rhizoctonia + Leuconostoc inoculations at harvest, the cultivar rankings showed no correlation with data from the field but did have a significant positive correlation twice with storage data.

In 2009 and 2010, when L. mesenteroides was inoculated alone, the number of roots with rot ranged from 4 to $15 \%$ in roots from the 26 commercial sugar beet cultivars, depending on year and inoculation time (data not shown). Because of the low incidence of rot associated with the Leuconostoc inoculation, analysis of variance and mean separation were not attempted with these data.

Based on isolations from 112 roots when $R$. solani was inoculated individually, $R$. solani could be confirmed $66 \%$ of the time, while $28 \%$ of the time $L$. mesenteroides was also present. Isolations from these same roots for the Rhizoctonia + Leuconostoc inoculation indicated that $L$. mesenteroides could be confirmed in $61 \%$ of the samples, whereas $R$. solani was only identified in $12 \%$ of the samples. Isolations from the Leuconostoc inoculation indicated that $L$. mesenteroides could be found in $100 \%$ of the samples, whereas $R$. solani was not isolated. Isolations where $R$. solani was involved were frequently hindered by bacterial and yeast contaminants. No rot or contaminants were evident in the noninoculated checks.

Across the greenhouse studies at harvest and after storage, contaminating fungal rot other than the dry black rot associated with

Table 5. Diameter of rotted area after 3 weeks in a greenhouse root assay with roots inoculated at harvest time with Rhizoctonia solani strain F508 inoculated alone or in combination with Leuconostoc mesenteroides subsp. dextranicum strain B322 into mature sugar beet roots of 26 commercial sugar beet cultivars harvested from disease-free field plots in 2009 and 2010 from a cultivar trial in American Falls, ID

\begin{tabular}{|c|c|c|c|c|}
\hline \multirow[b]{3}{*}{ Cultivar $^{\mathrm{y}}$} & \multicolumn{4}{|c|}{$\operatorname{Root} \operatorname{rot}(\mathbf{m m})^{x}$} \\
\hline & \multicolumn{2}{|c|}{ Rhizoctonia } & \multicolumn{2}{|c|}{ Rhizoctonia + Leuconostoc } \\
\hline & 2009 & 2010 & 2009 & 2010 \\
\hline HH015 & $27 \mathrm{a}-\mathrm{e}$ & $35 \mathrm{ab}$ & $24 b-f$ & $43 \mathrm{a}$ \\
\hline C-11 & $27 \mathrm{a}-\mathrm{e}$ & $36 \mathrm{a}$ & $15 \mathrm{f}$ & $42 \mathrm{ab}$ \\
\hline B-5 & $45 \mathrm{a}$ & $14 \mathrm{gh}$ & $24 b-f$ & $41 \mathrm{ab}$ \\
\hline B-34 & $29 \mathrm{a}-\mathrm{e}$ & $26 \mathrm{~b}-\mathrm{f}$ & $16 \mathrm{ef}$ & $36 a-c$ \\
\hline НH016 & $23 \mathrm{c}-\mathrm{e}$ & $26 b-f$ & $18 \mathrm{c}-\mathrm{f}$ & $34 \mathrm{a}-\mathrm{d}$ \\
\hline НМ080011 & $31 \mathrm{a}-\mathrm{e}$ & $30 \mathrm{a}-\mathrm{d}$ & $19 b-f$ & $32 \mathrm{a}-\mathrm{e}$ \\
\hline НM070006 & $23 \mathrm{c}-\mathrm{e}$ & $20 \mathrm{~d}-\mathrm{h}$ & $17 \mathrm{~d}-\mathrm{f}$ & $32 \mathrm{a}-\mathrm{e}$ \\
\hline B-37 & $29 \mathrm{a}-\mathrm{e}$ & $30 a-c$ & $34 \mathrm{ab}$ & $32 \mathrm{a}-\mathrm{e}$ \\
\hline НМ070022 & 12 ef & $13 \mathrm{gh}$ & $16 \mathrm{~d}-\mathrm{f}$ & $30 \mathrm{a}-\mathrm{e}$ \\
\hline $\mathrm{C}-25$ & $41 \mathrm{a}-\mathrm{c}$ & $17 \mathrm{f}-\mathrm{h}$ & $23 b-f$ & $30 \mathrm{~b}-\mathrm{e}$ \\
\hline C-27 & $42 \mathrm{a}-\mathrm{c}$ & $21 \mathrm{c}-\mathrm{h}$ & $39 a$ & $29 b-f$ \\
\hline C-19 & $27 \mathrm{a}-\mathrm{e}$ & $29 \mathrm{a}-\mathrm{e}$ & $20 \mathrm{~b}-\mathrm{f}$ & $25 \mathrm{c}-\mathrm{g}$ \\
\hline C-204 & $34 \mathrm{a}-\mathrm{d}$ & $32 \mathrm{ab}$ & $26 \mathrm{a}-\mathrm{f}$ & $25 \mathrm{c}-\mathrm{g}$ \\
\hline B-38 & $46 a$ & $26 b-f$ & $32 \mathrm{a}-\mathrm{d}$ & $25 \mathrm{c}-\mathrm{g}$ \\
\hline HМ080006 & $24 \mathrm{~b}-\mathrm{e}$ & $19 \mathrm{e}-\mathrm{h}$ & $16 \mathrm{~d}-\mathrm{f}$ & $25 \mathrm{c}-\mathrm{g}$ \\
\hline B-7 & $18 \mathrm{de}$ & $14 \mathrm{gh}$ & $19 b-f$ & $24 \mathrm{c}-\mathrm{g}$ \\
\hline HH017 & $42 \mathrm{a}-\mathrm{c}$ & $14 \mathrm{gh}$ & $23 b-f$ & $23 \mathrm{~d}-\mathrm{g}$ \\
\hline C-28 & $28 \mathrm{a}-\mathrm{e}$ & $22 \mathrm{c}-\mathrm{g}$ & $24 \mathrm{a}-\mathrm{f}$ & $23 \mathrm{~d}-\mathrm{g}$ \\
\hline C-29 & $44 \mathrm{ab}$ & 29 a-e & $30 \mathrm{a}-\mathrm{e}$ & $23 \mathrm{~d}-\mathrm{g}$ \\
\hline SV003 & $37 \mathrm{a}-\mathrm{d}$ & $22 \mathrm{c}-\mathrm{g}$ & $26 \mathrm{a}-\mathrm{f}$ & $22 \mathrm{~d}-\mathrm{g}$ \\
\hline SV007 & $30 \mathrm{a}-\mathrm{e}$ & $22 \mathrm{c}-\mathrm{g}$ & $33 a-c$ & $22 \mathrm{~d}-\mathrm{g}$ \\
\hline C-208 & $33 \mathrm{a}-\mathrm{d}$ & $26 \mathrm{a}-\mathrm{e}$ & $34 a b$ & $20 \mathrm{e}-\mathrm{g}$ \\
\hline C-12 & $47 \mathrm{a}$ & $26 \mathrm{a}-\mathrm{f}$ & $22 b-f$ & $18 \mathrm{fg}$ \\
\hline НМ080004 & $27 \mathrm{a}-\mathrm{e}$ & $32 \mathrm{ab}$ & $14 \mathrm{fg}$ & $17 \mathrm{fg}$ \\
\hline B-39 & $24 \mathrm{~b}-\mathrm{e}$ & $25 \mathrm{~b}-\mathrm{f}$ & $25 \mathrm{a}-\mathrm{f}$ & $17 \mathrm{fg}$ \\
\hline SV001 & $22 \mathrm{c}-\mathrm{e}$ & $10 \mathrm{hi}$ & $18 \mathrm{c}-\mathrm{f}$ & $13 \mathrm{gh}$ \\
\hline Noninoculated check & $0 \mathrm{f}$ & $0 \mathrm{i}$ & $0 \mathrm{~g}$ & $0 \mathrm{~h}$ \\
\hline Overall mean & 30 & 23 & 22 & 26 \\
\hline$P>F^{\mathrm{z}}$ & 0.0452 & $<0.0001$ & 0.0441 & $<0.0001$ \\
\hline
\end{tabular}

${ }^{\mathrm{x}}$ Rhizoctonia $=$ root inoculated with $R$. solani strain F508. Rhizoctonia + Leuconostoc $=$ root inoculated with $R$ solani strain F508 plus $L$. mesenteroides subsp. dextranicum strain B322. Means within a column followed by the same letter did not differ significantly based on least square means $(\alpha=$ $0.05)$.

y All cultivar names are coded ( $\mathrm{B}=$ Betaseed Inc., $\mathrm{C}=\mathrm{ACH}$ Seed Inc., HH = Holly Hybrids, HM = Hilleshog, and SV = SESVanderHave) but the respective companies can be contacted using the code to gain additional information on the cultivars.

${ }^{\mathrm{z}} P>F$ was the probability associated with the $F$ value. Data were analyzed in SAS using Proc GLIMMIX. 
Table 6. Diameter of rotted root area after 2 weeks in a greenhouse root assay with roots inoculated after 60 days in storage with Rhizoctonia solani strain F508 inoculated alone or in combination with Leuconostoc mesenteroides subsp. dextranicum strain B322 into mature sugar beet roots of 26 commercial sugar beet cultivars harvested from disease-free plots in the 2009 and 2010 cultivar trials in American Falls, ID

\begin{tabular}{|c|c|c|c|c|}
\hline \multirow[b]{3}{*}{ Cultivar $^{\mathrm{y}}$} & \multicolumn{4}{|c|}{ Root rot $(\mathrm{mm})^{x}$} \\
\hline & \multicolumn{2}{|c|}{ Rhizoctonia } & \multicolumn{2}{|c|}{ Rhizoctonia + Leuconostoc } \\
\hline & 2009 & 2010 & 2009 & 2010 \\
\hline HМ080011 & 16 & 16 & $30 \mathrm{~b}-\mathrm{e}$ & 22 \\
\hline C-28 & 21 & 18 & $21 \mathrm{f}-\mathrm{j}$ & 20 \\
\hline C-11 & 17 & 19 & $17 \mathrm{ij}$ & 20 \\
\hline C-204 & 18 & 18 & $28 \mathrm{~b}-\mathrm{g}$ & 19 \\
\hline HH015 & 15 & 13 & $31 \mathrm{~b}-\mathrm{d}$ & 18 \\
\hline НH016 & 14 & 14 & $15 \mathrm{ij}$ & 18 \\
\hline HH017 & 14 & 15 & $21 \mathrm{f}-\mathrm{j}$ & 18 \\
\hline SV001 & 15 & 15 & $20 \mathrm{f}-\mathrm{j}$ & 17 \\
\hline C-208 & 17 & 14 & $30 \mathrm{~b}-\mathrm{e}$ & 17 \\
\hline C-29 & 14 & 14 & $32 \mathrm{bc}$ & 17 \\
\hline B-39 & 12 & 16 & $29 \mathrm{~b}-\mathrm{f}$ & 17 \\
\hline B-37 & 18 & 19 & $21 \mathrm{e}-\mathrm{j}$ & 16 \\
\hline B-38 & 16 & 16 & $36 \mathrm{ab}$ & 16 \\
\hline B-7 & 13 & 12 & $18 \mathrm{~h}-\mathrm{j}$ & 15 \\
\hline SV007 & 18 & 13 & $24 \mathrm{c}-\mathrm{i}$ & 15 \\
\hline HМ080004 & 16 & 16 & $22 \mathrm{~d}-\mathrm{j}$ & 15 \\
\hline C-12 & 20 & 17 & $21 \mathrm{e}-\mathrm{j}$ & 14 \\
\hline SV003 & 17 & 15 & $23 \mathrm{c}-\mathrm{i}$ & 14 \\
\hline B-34 & 15 & 16 & $17 \mathrm{ij}$ & 14 \\
\hline C-27 & 16 & 15 & $44 \mathrm{a}$ & 14 \\
\hline HМ070006 & 14 & 12 & $14 \mathrm{j}$ & 14 \\
\hline HМ070022 & 14 & 11 & $20 \mathrm{f}-\mathrm{j}$ & 14 \\
\hline HМ080006 & 15 & 12 & $23 \mathrm{c}-\mathrm{i}$ & 13 \\
\hline C-25 & 21 & 13 & $27 \mathrm{~b}-\mathrm{h}$ & 13 \\
\hline B-5 & 17 & 15 & $19 \mathrm{~g}-\mathrm{j}$ & 12 \\
\hline C-19 & 17 & 13 & $28 \mathrm{~b}-\mathrm{g}$ & 12 \\
\hline Check & 0 & 0 & $0 \mathrm{k}$ & 0 \\
\hline Mean & 16 & 14 & 23 & 15 \\
\hline$P>F^{\mathrm{z}}$ & 0.0766 & 0.2155 & $<0.0001$ & 0.1631 \\
\hline
\end{tabular}

${ }^{\times}$Rhizoctonia $=$root inoculated with $R$. solani strain F508. Rhizoctonia + Leuconostoc $=$ root inoculated with $R$. solani strain F508 plus Leuconostoc mesenteroides subsp. dextranicum strain B322. Means within a column followed by the same letter did not differ significantly based on least square means $(\alpha=0.05)$.

y All cultivar names are coded (B = Betaseed Inc., $\mathrm{C}=\mathrm{ACH}$ Seed Inc., $\mathrm{HH}=$ Holly Hybrids, HM = Hilleshog, and SV = SESVanderHave) but the respective companies can be contacted using the code to gain additional information on the cultivars. Check $=$ noninoculated check and Mean $=$ overall mean.

${ }^{\mathrm{z}} P>F$ was the probability associated with the $F$ value. Data were analyzed in SAS using Proc GLIMMIX.

R. solani was present in $21 \%$ of the Rhizoctonia inoculations, $7 \%$ of the Rhizoctonia + Leuconostoc inoculations, and none of the Leuconostoc inoculations. Based on 60 isolations from the contaminating fungal rots, Rhizopus spp. and Aspergillus spp. were present 52 and $48 \%$ of the time, respectively.

\section{Discussion}

Previous work evaluating Rhizoctonia root rot in sugar beet roots has been focused on fungal rot $(3,9,30,32)$ but, recently, a bacterial root rot process was discovered and described (39). Cultivar evaluation for bacterial root rot for stored roots has been described (37) but it is not applicable to large screening nurseries and likely does not relate to the field. The current study evaluates the Rhizoctonia-bacterial root rot complex in both the field and storage environments. Although there was a strong relationship among the four (fungal, bacterial, total, and surface) variables evaluated in the field, surface rot was the best for cultivar separation based on rankings, had the largest range of values, and also performed as well as any of the other variables for mean separation. Rating the root surface also is faster and easier, because the root does not need to be bisected as it does for the other three variables.

In the 2010 and 2011 field studies, the four Rhizoctonia-bacterial disease variables (fungal, bacterial, total internal, and surface rot) all resulted in significant $(P<0.0001)$ cultivar differences. Based on regression analysis, strong positive relationships $(P<$ $0.0001)$ were present among the disease variables. When ranking cultivars, the most consistent variable was surface rot, because 12 of 13 variable-year combinations had significant correlations. The greenhouse assay at harvest with mature roots from the field allowed for good cultivar separation with $R$. solani inoculations both with and without Leuconostoc. After the roots had been stored for 60 days, cultivar separation with the greenhouse assay was marginal or not possible. When cultivar ranking in the greenhouse assays were compared, there was frequently a positive correlation with storage data but, when compared with field results, there was no relationship. Thus, the greenhouse assay seems to relate to storage and will not substitute for conducting field screening. Fungal strain comparisons with the greenhouse assay at harvest indicated that all $R$. solani strains were pathogenic but establishing consistent differences between strains across years was problematic. When conducting comparisons with both $R$. solani and $L$. mesenteroides strains in the future, work will likely have to be done with mature roots in the field because, if roots are removed from the field, there is a storage response and not a field response.

Previous studies have shown that the bacterial root rot in sugar beet appeared to frequently be associated with Rhizoctonia root rot in the field $(36,40)$. However, the fungal rot was only associated with 3 to $5 \%$ of the root mass and the majority of the rot, 6 to > $70 \%$ of the root mass, was related to bacterial rot (40). The field studies in 2010 and 2011 support these earlier findings, because fungal rot means ranged from 0 to $8 \%$ and bacterial rot means ranged from 0 to $37 \%$. The regression analysis also indicated there was a strong positive relationship $(P<0.0001)$ between the surface, fungal, and bacterial rots.

Although there is a link with Rhizoctonia root rot, bacterial root rot appeared to occasionally be initiated without the presence of fungal rot at times in previous field collections and studies $(39,40)$. In the six studies conducted under greenhouse conditions with $L$. mesenteroides inoculated individually, there was only a low frequency ( 0 to $15 \%$ of roots) of bacterial root rot established and isolations always confirmed the presence of L. mesenteroides. These data fit with what has been seen in previous field observations and studies $(39,40)$. However, when L. mesenteroides was combined with $R$. solani, there was rot in every root and each root had twice as much internal rot as when $R$. solani was inoculated alone. Thus, these data provide support that $R$. solani has a synergistic interaction with $L$. mesenteroides, which helps establish the bacterial root rot phase. However, the data also indicate that there may be some inhibition by the $L$. mesenteroides associated with bacterial root rot. When $R$. solani was inoculated with $L$. mesenteroides, $R$. solani could only be isolated from $12 \%$ of the samples in greenhouse assays at harvest and after storage. However, when $R$. solani was inoculated individually, it was isolated from $66 \%$ of the samples; however, L. mesenteroides was also isolated from $28 \%$ of these samples. Because the roots were not sterilized prior to inoculation, contaminating dust from the air and root surface could have gotten in the inoculation site when the plug was removed and replaced. However, the noninoculated checks and the $L$. mesenteroides-only inoculations did not have problems with contaminants. These data help clarify the synergistic role $R$. solani appears to play in allowing other organisms to invade and become established in the root tissue.

The isolation and contaminant data indicate that $R$. solani frequently allowed not only bacteria to get established in the root but fungal contaminants as well. When $R$. solani was inoculated individually in the greenhouse assays at harvest and after storage, fungal contaminants (Rhizopus spp. and Aspergillus spp.) became established in $21 \%$ of these inoculations, whereas this was observed in only $7 \%$ of the Rhizoctonia + Leuconostoc inoculations. In the noninoculated checks and when L. mesenteroides was inoculated individually, there were no fungal contaminants observed. In Michigan fields, $R$. solani was recently documented to interact 
Table 7. Spearman's rank correlation for 26 commercial sugar beet cultivars using variables evaluated in the field, greenhouse, and storage in Idaho

\begin{tabular}{|c|c|c|c|c|c|c|c|c|}
\hline \multirow[b]{4}{*}{ Variable (year, treatment) ${ }^{\mathrm{z}}$} & \multicolumn{8}{|c|}{ Greenhouse assays $^{y}$} \\
\hline & \multicolumn{4}{|c|}{ Inoculated at harvest } & \multicolumn{4}{|c|}{ Inoculated after 60 days in storage } \\
\hline & \multicolumn{2}{|c|}{ Rhizoctonia solani } & \multicolumn{2}{|c|}{ R. solani + Leuconostoc } & \multicolumn{2}{|c|}{ R. solani } & \multicolumn{2}{|c|}{ R. solani + Leuconostoc } \\
\hline & 2009 & 2010 & 2009 & 2010 & 2009 & 2010 & 2009 & 2010 \\
\hline $2009 \mathrm{R}$ at harvest in $\mathrm{GH}$ & 1.000 & $\ldots$ & $\ldots$ & $\ldots$ & $\ldots$ & $\ldots$ & $\ldots$ & $\ldots$ \\
\hline $2010 \mathrm{R}$ at harvest in $\mathrm{GH}$ & 0.201 & 1.000 & $\ldots$ & $\ldots$ & $\ldots$ & $\ldots$ & $\ldots$ & $\ldots$ \\
\hline $2009 \mathrm{R}+\mathrm{L}$ at harvest in $\mathrm{GH}$ & $0.607 * *$ & 0.134 & 1.000 & $\ldots$ & $\ldots$ & $\ldots$ & $\ldots$ & $\ldots$ \\
\hline $2010 \mathrm{R}+\mathrm{L}$ at harvest in $\mathrm{GH}$ & -0.071 & 0.182 & -0.183 & 1.000 & $\ldots$ & $\ldots$ & $\ldots$ & $\ldots$ \\
\hline $2009 \mathrm{R}$ after storage in $\mathrm{GH}$ & $0.516^{* *}$ & 0.274 & $0.346^{*}$ & -0.035 & 1.000 & $\ldots$ & $\ldots$ & $\ldots$ \\
\hline $2010 \mathrm{R}$ after storage in $\mathrm{GH}$ & $0.452 * *$ & $0.510 * *$ & 0.271 & 0.022 & $0.437 * *$ & 1.000 & $\ldots$ & $\ldots$ \\
\hline $2009 \mathrm{R}+\mathrm{L}$ after storage in $\mathrm{GH}$ & $0.454 * *$ & $0.345 *$ & $0.582 * *$ & -0.240 & 0.198 & 0.058 & 1.000 & $\ldots$ \\
\hline $2010 \mathrm{R}+\mathrm{L}$ after storage in $\mathrm{GH}$ & -0.043 & $0.459 * *$ & 0.143 & -0.042 & 0.003 & $0.473 * *$ & 0.103 & 1.000 \\
\hline $2010 \mathrm{R}$ in field, percent fungal & -0.021 & -0.150 & -0.069 & -0.014 & 0.104 & -0.059 & 0.028 & -0.162 \\
\hline $2010 \mathrm{R}$ in field, percent bacterial & 0.034 & -0.132 & -0.016 & -0.162 & 0.201 & 0.003 & -0.010 & -0.212 \\
\hline $2010 \mathrm{R}$ in field, percent total & 0.030 & -0.128 & -0.036 & -0.128 & 0.188 & 0.001 & -0.001 & -0.172 \\
\hline $2010 \mathrm{R}$ in field, percent surface & -0.008 & -0.203 & -0.001 & -0.075 & 0.100 & -0.136 & 0.088 & -0.186 \\
\hline $2011 \mathrm{R}$ in field, percent fungal & -0.169 & -0.195 & -0.064 & -0.110 & -0.014 & $-0.382 *$ & 0.094 & -0.295 \\
\hline $2011 \mathrm{R}$ in field, percent bacterial & -0.225 & -0.243 & 0.017 & -0.149 & -0.017 & $-0.455^{* *}$ & 0.180 & -0.321 \\
\hline $2011 \mathrm{R}$ in field, percent total & -0.232 & -0.236 & 0.003 & -0.144 & -0.011 & $-0.451 * *$ & 0.156 & -0.317 \\
\hline $2011 \mathrm{R}$ in field, percent surface & -0.149 & -0.236 & -0.036 & -0.119 & 0.011 & $-0.427 * *$ & 0.183 & -0.399 \\
\hline
\end{tabular}

${ }^{\text {y }}$ Leuconostoc $=$ Leuconostoc mesenteroides, $* *=r$ value significant with $P \leq 0.05$, and $*=r$ value significant with $P \leq 0.10$.

${ }^{\mathrm{z}} \mathrm{R}=$ inoculated with $R$. solani, $\mathrm{R}+\mathrm{L}=$ inoculated with both $R$. solani and Leuconostoc mesenteroides, at harvest in GH $=$ inoculated at harvest in the greenhouse assay, at storage in $\mathrm{GH}=$ inoculated after 60 days in storage in the greenhouse assay, in field = inoculated at eight-leaf growth stage in field, percent fungal $=$ percentage of internal root mass with dry black fungal rot caused by $R$. solani, percent bacterial $=$ percentage of internal root mass with wet bacterial rot, percent total = percentage of internal root mass with fungal or bacterial rot, and percent surface $=$ percentage of rotted root surface.

with Rhizopus stolonifer, leading to additional rot (18). In Idaho, Rhizoctonia solani appears to facilitate the entry of both bacterial and fungal contaminants, which leads to increased rot in root tissue $(36,39,40)$.

Bacterial rots typically contain other bacteria or yeast that get established in the rotted tissue along with $L$. mesenteroides (39). However, previous studies show bacteria in the soil, root surface, and contaminated rotted tissue cause little or no rot on their own but will reduce rot caused by $R$. solani or $L$. mesenteroides $(25,26,39,46)$. Following the initiation of the fermentation or rotting process started by $L$. mesenteroides, this bacterium is typically superseded by other bacteria and yeast $(1,2,16,20)$. These bacteria and yeast that supersede $L$. mesenteroides likely explain some of the difficulty in isolating both $R$. solani and $L$. mesenteroides. These bacteria also likely explain why $R$. solani is limited to just the outer portion of the root in Idaho and reduced the frequency of fungal contaminants in greenhouse assays. To limit the influence of contaminating bacteria and fungi, the greenhouse assay conducted at harvest time potentially would benefit from a shorter incubation period such as 2 weeks rather than 3 weeks.

When Rhizoctonia root rot was limited by resistance, the bacterial root rot was also limited in comparisons between the disease variables based on both regression and Spearman's coefficient of rank analysis. This observation is important because good resistance to $R$. solani alone should allow for control of the Rhizoctonia-bacterial root rot complex. Traditionally, Rhizoctonia root rot has been evaluated by placing roots into disease classes based on a 0 -to-7 scale (32) or a 0-to-9 scale (9). In the present study, percentage data were utilized so that both fungal and bacterial rot could be assessed simultaneously and in a continuous manner. However, if identifying Rhizoctonia root rot resistance is the goal, then all approaches mentioned should work. When selecting for resistance in the field, surface observations on the root should be sufficient, because both surface and internal observations were highly related. Hopefully good resistance can be incorporated into a higher percentage of the commercial cultivars, because many cultivars were more susceptible than the resistant check. To supplement host resistance, good crop rotations $(7,8,14,23,31,33,45)$ and fungicide applications $(5,21,22,42,44)$ will likely be needed. Also, resistance to rot in the field appears to be different from controlling rot in storage. Thus, research to control rot in the field and storage will have to be considered independently.

\section{Acknowledgments}

These data support the objectives for the United States Department of Agriculture CRIS project 5368-21220-003-00D. We thank the Amalgamated Sugar Co., Beet Sugar Development Foundation, and Snake River Sugar beet Growers for supporting our research work; and J. Reed, D. Kenney, and T. Brown for their technical support.

\section{Literature Cited}

1. Amoa-Awua, W. K., Sampson, E., and Tano-Debrah, K. 2007. Growth of yeasts, lactic and acetic acid bacteria in palm wine during tapping and fermentation from felled oil palm (Elaeis guineensis) in Ghana. J. Appl. Microbiol. 102:599-606.

2. Andesogan, A. T., Salawu, M. B., Ross, A. B., Davies, D. R., and Brooks, A. E. 2003. Effect of Lactobacillus buchneri, Lactobacillus fermentum, Leuconostoc mesenteroides, or a chemical additive on the fermentation, aerobic stability, and nutritive value of crimped wheat grains. J. Dairy Sci. 86:1789-1796.

3. Behn, A., Ladewig, E., Manthey, R., and Varrelmann, M. 2012. Resistance testing of sugar beet varieties against Rhizoctonia solani. Sugar Ind. 137:4957.

4. Benkerroum, N., Misbah, M., Sandine, W. E., and Elaraki, A. T. 1993. Development and use of a selective medium for isolation of Leuconostoc spp. from vegetables and dairy products. Appl. Environ. Microbiol. 59:607-609.

5. Bolton, M. D., Panella, L., Campbell, L., and Khan, M. 2010. Temperature, moisture, and fungicide effects in managing Rhizoctonia root and crown rot of sugar beet. Phytopathology 100:689-697.

6. Breidt, F., Jr. 2004. A genomic study of Luconostoc mesenteroides and the molecular ecology of sauerkraut fermentations. J. Food Sci. 69:30-32.

7. Buddemeyer, J., Pfähler, B., Peterson, J., and Märländer, B. 2004. Genetic variation in susceptibility of maize to Rhizoctonia solani (AG 2-2IIIB)symptoms and damage under field conditions in Germany. J. Plant Dis. Prot. 111:521-533.

8. Buhre, C., Kluth, C., Bürcky, K., Märländer, B., and Varrelmann, M. 2009. Integrated control of root and crown rot in sugar beet: combined effects of cultivar, crop rotation, and soil tillage. Plant Dis. 93:155-161.

9. Büttner, G., Pfähler, B., and Märländer, B. 2004. Greenhouse and field techniques for testing sugar beet for resistance to Rhizoctonia root and crown rot. Plant Breed. 123:158-166.

10. Cai, Y., Kumai, S., Ogawa, M., Benno, Y., and Nakase, T. 1999. Characterization and identification of Pediococcus species isolated from forage crops and their application for silage preparation. Appl. Environ. Microbiol. 65:2901-2906.

11. Chen, Y.-S., Yanagida, F., and Shinohara, T. 2005. Isolation and identification of lactic acid bacteria from soil using an enrichment procedure. Lett. Appl. Microbiol. 40:195-200.

12. Cogan, T. M., and Jordan, K. N. 1994. Metabolism of Leuconostoc bacteria. J. Dairy Sci. 77:2704-2717.

13. Cubeta, M. A., and Vilgalys, R. 1997. Population biology of the Rhizoctonia solani complex. Phytopathology 87:480-484.

14. Engelkes, C. A., and Windels, C. E. 1996. Susceptibility of sugar beet and 
beans to Rhizoctonia solani AG-2-2 IIIB and AG-2-2IV. Plant Dis. 80:14131417.

15. Führer Ithurrart, M. E., Büttner, G., and Peterson, J. 2004. Rhizoctonia root rot in sugar beet (Beta vulgaris ssp. altissima) - epidemiological aspects in relation to maize (Zea mays) as a host plant. J. Plant Dis. Prot. 111:302-312.

16. Gardner, N. J., Savard, T., Obermeier, P., Caldwell, G., and Champagne, C. P. 2001. Selection and characterization of mixed starter cultures for lactic acid fermentation of carrot, cabbage, beet and onion vegetable mixtures. Int. J. Food Microbiol. 64:261-275.

17. Gaskill, J. O. 1968. Breeding for Rhizoctonia resistance in sugarbeet. J. Am. Soc. Sugar Beet Technol. 15:107-119.

18. Hansen, L. E. 2010. Interaction of Rhizoctonia solani and Rhizopus stolonifer causing root rot of sugar beet. Plant Dis. 94:504-509.

19. Holt, J. G., Krieg, N. R., Sneath, P. H. A., Staley, J. T., and Williams, S. T., eds. 1994. Bergy's Manual of Determinative Bacteriology, 9th ed. Williams and Wilkins, Baltimore, MD.

20. Jung, J. Y., Lee, S. H., Lee, H. J., Seo, H.-Y., Park, W.-S., and Jeon, C. O. 2012. Effects of Leuconostoc mesenteroides starter cultures on microbial communities and metabolites during kimchi fermentation. Int. J. Food Microbiol. 153:378-387.

21. Kiewnick, S., Jacobsen, B. J., Braun-Kiewnick, A., Eckhoff, J. L. A., and Bergman, J. W. 2001. Integrated control of Rhizoctonia crown and root rot of sugar beet with fungicides and antagonistic bacteria. Plant Dis. 85:718722.

22. Kirk, W. W., Wharton, P. S., Schafer, R. L., Tumbalam, P., Poindexter, S., Guza, C., Fogg, R., Schlatter, T., Stewart, J., Hubbell, L., and Ruppal, D. 2008. Optimizing fungicide timing for the control of Rhizoctonia crown and root rot of sugar beet using soil temperature and plant growth stages. Plant Dis. 92:1091-1098.

23. Kluth, C., and Verrelmann, M. 2010. Maize genotype susceptibility to Rhizoctonia solani and its effect on sugar beet crop rotations. Crop Prot. 29:230-238.

24. Lein, J. C., Sagstetter, C. M., Schulte, D., Thurau, T., Varrelmann, M., Saal, B., Koch, G., Borchardt, D. C., and Jung, C. 2008. Mapping of Rhizoctonia root rot resistance genes in sugar beet using pathogen response-related sequences as molecular markers. Plant Breed. 127:602-611.

25. Lovic, B., Heck, C., Gallian, J. J., and Anderson, A. J. 1993. Inhibition of the sugarbeet pathogens Phoma betae and Rhizoctonia solani by bacteria associated with sugarbeet seeds and roots. J. Sugar Beet Res. 30:169-184.

26. Mendes, R., Kruijt, M., de Bruijn, I., Dekkers, E., van der Voort, M., Schneider, J. H. M., Piceno, Y. M., DeSantis, T. Z., Andersen, G. L., Bakker, P. A. H. M., and Raaijmakers, J. M. 2011. Deciphering the rhizosphere microbiome for disease-suppressive bacteria. Science 332:1097-1100.

27. Ohkura, M., Abawi, G. S., Smart, C. D., and Hodge, K. T. 2009. Diversity and aggressiveness of Rhizoctonia solani and Rhizoctonia-like fungi on vegetables in New York. Plant Dis. 93:615-624.

28. Orberg, P. K., and Sandine, W. E. 1984. Common occurrence of plasmid DNA and vancomycin resistance in Leuconostoc spp. Appl. Environ. Microbiol. 48:1129-1133.

29. Panella, L. 2005. Root rots. Pages $95-98$ in: Genetics and Breeding of Sugar Beet. E. Biancardi, L. G. Campbell, G. N. Skaracis, and M. de Biaggi, eds. Science Publishers, Enfield, NH.

30. Reynolds, G. J., Windels, C. E., MacRae, I. V., and Laguette, S. 2012. Re- mote sensing for assessing Rhizoctonia crown and root rot severity in sugar beet. Plant Dis. 96:497-505.

31. Ruppel, E. G. 1985. Susceptibility of rotation crops to a root rot isolate of Rhizoctonia solani from sugar beet and survival of the pathogen in crop residues. Plant Dis. 69:871-873.

32. Ruppel, E. G., Schneider, C. L., Hecker, R. J., and Hogaboam, G. J. 1979. Creating epiphytotics of Rhizoctonia root rot and evaluating for resistance to Rhizoctonia solani in sugarbeet field plots. Plant Dis. Rep. 63:518-522.

33. Rush, C. M., and Winter, S. R. 1990. Influence of previous crops on Rhizoctonia root and crown rot of sugar beet. Plant Dis. 74:421-425.

34. Schaad, N. W. 2001. Initial identification of common genera. Pages 1-6 in Laboratory Guide for Identification of Plant Pathogenic Bacteria, 3rd ed. N. W. Schaad, J. B. Jones, and W. Chun, eds. American Phytopathological Society, St. Paul, MN.

35. Sever-Busson, C., Foucaud, C., and Leveau, J.-Y. 1999. Selection of dairy Leuconostoc isolates for important technological properties. J. Dairy Res. $66: 245-256$.

36. Strausbaugh, C. A., and Eujayl, I. A. 2012. Influence of sugarbeet tillage systems on the Rhizoctonia-bacterial root rot complex. J. Sugar Beet Res. 49(3-4):57-78.

37. Strausbaugh, C. A., Eujayl, I. A., and Foote, P. 2010. Sugarbeet cultivar evaluation for bacterial root rot. J. Sugar Beet Res. 47:51-64.

38. Strausbaugh, C. A., Eujayl, I. A., Panella, L. W., and Hanson, L. E. 2011. Virulence, distribution, and diversity of Rhizoctonia solani from sugar beet in Idaho and Oregon. Can. J. Plant Pathol. 33:210-226.

39. Strausbaugh, C. A., and Gillen, A. M. 2008. Bacteria and yeast associated with sugar beet root rot at harvest in the Intermountain West. Plant Dis. 92:357-363.

40. Strausbaugh, C. A., and Gillen, A. M. 2009. Sugar beet root rot at harvest in the US Intermountain West. Can. J. Plant Pathol. 31:232-240.

41. Strausbaugh, C. A., Rearick, E., Eujayl, I., and Foote, P. 2011. Influence of Rhizoctonia-bacterial root rot complex on storability of sugarbeet. J. Sugar Beet Res. 48:155-180.

42. Stump, W. L., Franc, G. D., Harveson, R. M., and Wilson, R. G. 2004 Strobilurin fungicide timing for Rhizoctonia root and crown rot suppression in sugarbeet. J. Sugar Beet Res. 41:17-37.

43. Tallgren, A. H., Airaksinen, U., von Weissenberg, R., Ojamo, H., Kuusisto, J., and Leisola, M. 1999. Exoploysaccharide-producing bacteria from sugar beets. Appl. Environ. Microbiol. 65:862-864.

44. Windels, C. E., and Brantner, J. R. 2005. Early-season application of azoxystrobin to sugarbeet for control of Rhizoctonia solani AG 4 and AG 22. J. Sugar Beet Res. 42:1-17.

45. Woodhall, J. W., Belcher, A. R., Peters, J. C., Kirk, W. W., and Wharton, P. S. 2012. First report of Rhizoctonia solani AG2-2IIB infecting potato stems and stolons in the United States. Plant Dis. 96:460.

46. Zachow, C., Grosch, R., and Berg, G. 2011. Impact of biotic and a-biotic parameters on structure and function of microbial communities living on sclerotia of the soil-borne pathogenic fungus Rhizoctonia solani. Appl. Soil Ecol. 48:193-200.

47. Zarazaga, M., Sáenz, Y., Portillo, A., Tenorio, C., Ruiz-Larrea, F., Del Campo, R., Baquero, F., and Torres, C. 1999. In vitro activities of ketolide HMR3647, macrolides, and other antibiotics against Lactobacillus, Leuconostoc, and Pediococcus isolates. Antimicrob. Agents Chemother. 43:3039-3041. 